\title{
Ontology of African Ritual
}

\author{
Francis Etim \\ Department of Philosophy, University of Uyo, Uyo, Akwa-Ibom State, Nigeria \\ Email: etimfrank@yahoo.com
}

How to cite this paper: Etim, F. (2019). Ontology of African Ritual. Advances in Applied Sociology, 9, 1-14.

https://doi.org/10.4236/aasoci.2019.91001

Received: November 26, 2018

Accepted: January 5, 2019

Published: January 7, 2019

Copyright $\odot 2019$ by author and Scientific Research Publishing Inc. This work is licensed under the Creative Commons Attribution International License (CC BY 4.0).

http://creativecommons.org/licenses/by/4.0/

\begin{abstract}
African rituals, like other phenomena of African cultural heritage are usually faced with criticisms of being either superstitious, fetish, mundane or simply irrational. These criticisms, often based on certain logical criteria, have categorized the African mode of thinking as illogical, unreasonable and non-rational. Given the proclivity of the African mode of thinking of fusing the epistemological into the metaphysical, such criticism could either be excused or be regarded as a misinterpretation, misrepresentation and non-sequitur. However, the issue at stake calls for a deep examination of some of these phenomena to establish their reasonableness as veritable reality among Africans with serious existential import. One of such phenomena is ritual, which is actually pervasive as far as African existential reality is concerned. This paper examines African ritual to establish its reasonableness by establishing its ontology. The paper argues that based on African ontology, African rituals cannot be judged on the principles of Western scientific rationality but rather should be seen as a non-rational action like other human phenomenon like love or possessing rationality internal to the metaphysical beliefs that underpin the African worldview.
\end{abstract}

\section{Keywords}

Ontology, Rituals, African Ontology, Space, Time

\section{Introduction}

Man is variously described as Homo faber (a working animal), Homo religiosus (a religious being), Homo loquen (a speaking being), Homo symbolicus (a symbolic being), etc. All these descriptions and ascriptions according to some Anthropologists are premised on the fact that man is considered to be Homo rationalis (rational being) with the innate capacity to create and interpret symbols. With this aptitude man is capacitated to formulate and to interpret, among other things, his language, rituals and culture in general. Ritual then is man's creative 
action as a symbolic being. So ritual can be said to be strictly a human affair.

Ritual actions have always generated serious metaphysical, epistemological and logical issues given its esoteric nature, its association with symbolism and its integration with belief, be it in civilized, non-civilized, developed or underdeveloped cultures. Issue like, is ritual real? Is it rational? How do actions like imposition of hand, pouring of water, infliction of pains on effigy produce an effect, whether immediate or in proxy? How does one identify the necessary connection between an action and the effect it is believed to cause? How do simple actions like exchange of vows and conferment of title transform two people into husband and wife and a king or a chief respectively? What is the role of belief in ritual efficacy? And so on.

In the case of African ritual action, these issues raised are compounded by African mind-set that fuses metaphysics into epistemology resulting in the esoteric nature of African perception of reality. The logical implication is to simply classify African rituals as superstitious especially by one who is not quite familiar with African mind-set. No doubt, belief plays a tremendous role in understanding and appreciating ritual action. But beliefs are not isolated phenomena but are off shoots of people's metaphysics and epistemology. It is within this thought frame that examining the ontology of African rituals is contemplated as a way of enhancing a better understanding and appreciation of African rituals within the African sitz im leben. Ontology is specifically concerned with being. Within this context of our consideration, it has to do with the set of concepts and categories within African context that influence and inform African beliefs and actions. It provides basic explanation to beliefs, worldviews and issues that may not be easily understood at face value. Examining the ontology of African ritual goes beyond the gestures and actions to the basic categories that serve as an explanandum that provides deeper meaning to the phenomenon of rituals within the African context.

\section{What Is a Ritual?}

Etymologically, ritual is derived from the Latin word ritus, meaning "customs" or "rites", "series of actions that are always carried out in the same way, especially as part of religious ceremonies"; "socio cultural action, which is shared action expressive of common striving rooted in common values" (Fromm, 1950); a symbolic action with reference to the supernatural beings and the mystical; "actions that are always done at fixed times and in the same way especially as part of religious or other ceremonies" (Oxford Advanced Dictionary, 2010). Within religious perspective it is also referred to as a liturgical action, which is a repetitive and prescribed manner for public worship. Rituals then for Ranger (1972) “is a dramatization of ideals, values and expectations; a bridge between ideas and practical daily life".

Besides, ritual is seen as a culturally-patterned-symbolic action, thus bearing the label and image of a particular culture with its corpus of values and beliefs. It 
involves the use of objects and signs which constitute a set of symbols that represent and express reality at various levels, physical and metaphysical. "An object therefore qualified or is designated as a ritual object, is one whose meaning is shared in practice given a common cultural heritage" (Ranger, 1972).

Being the conveyor of the value of the society, ritual ought to endure. Thus for any ritual to endure (that is, stand the test of time), it must have a rigid character such that it does not give way or change indiscriminately. It must persist amidst novelty. This is why V. W. Turner (1962) calls it "quintessential custom". Freud sees ritual as "obsessive action, comparable to that of neurotics" (cited in Bocock, 1974). Though, as observed by Bocock, there are apparent resemblance between neurotic ceremonials and the sacred acts of religious rituals but the differences are equally obvious as to make the comparison sacrilegious. For instance, Bocock (1974) observes among other reasons, the fact that, it is collective and is distinct in this respect from the obsessive acts of neurotics. Again, the minutiae of religious ceremonial are full of significance and have symbolic meaning, while those of neurotics seem foolish and senseless. In this respect "an obsessional neurosis presents a travesty, half comic and half tragic, of a private religion" For Max Gluckman (1962), the term ritual is reserved for ceremony with a specific reference to mystical motions, which Bocock (1974) explicitly refer to as "religious rituals".

\section{Nature and Functions of Rituals}

Actually, rituals span the entire spectrum of human life. On this note, Bocock (1974) submits that besides religious rituals, there are aesthetic rituals like in the performing arts, rituals of life cycle and life crises, civil and political rituals. In industrial societies, they are independent of themselves while in traditional societies, they are unified whole.

T.O Ranger (1972) sees ritual as constituted of four structures thus:

1) Symbolic structure-that ritual is an aggregate of symbols, a totality of which aid adequate understanding of human society.

2) Value structure-that ritual is expressive of authoritative message about crucial values and relationship between values.

3) Telic-that sees ritual as performed for the sake of an end; designed to have effect on the people and bears the concern of posterity and future generations.

4) Role structure-implies ritual as the product of interaction of different human action representing different social categories/classes and not a product of individual ingenuity and initiative. So, it transcends individual/subjective interest of those who take part in it but tends to embrace the common good.

Based on major purpose and reason of performance, Ranger (1972) categorized African rituals into three types: redressive, life-crisis and liminal. Redressive ritual is performed to redress calamity, affliction or plague which has brought about some sort of crises in the community. It may be natural disaster like drought, famine, high mortality rate, etc., or sickness (most times incurable), ailment or such afflictions as sterility, barrenness, leprosy or any form of epi- 
demic, etc., that has stricken an individual so that he then becomes a symbolic representative of the people. After recourse to divination to unravel the cause and the social structure involvement directly or indirectly in causing the disaster, a ritual is performed to make hidden tensions explicit, expose the fault(s), "appease the gods" as it were and restore peace and harmony.

Life-crisis ritual is much more concerned with society as a whole than with the individual's interest. This sort of ritual introduces or initiates the individual into a specific community, cult association or category, social class/position. Such ritual would include circumcision and puberty rituals, funeral rites and various forms of initiation into confraternities.

Liminal ritual is associated with rites of passage from one social position to another. It depicts a window period of stability, ambiguity, passivity, lack of identity and lack of social status. It is demonstrated clearly in the case of the fattening room ritual which initiates young girls into womanhood. It could also be apprehended as that moment of orientation and tutelage that immediately precedes the assumption of desired social status.

Rituals take different and various forms ranging from:

- Prayers, entreaty and exorcism when addressing the supernatural.

- Music, dancing, chanting and playing of instruments.

- Mystical and psychological manipulations by the use of drugs, fasting, abstinence, exhortation, exercises, recitation, etc.

- Separation and leaving homes to stay in designated places like forests, deserts, etc.

- Application of simulated metaphysical powers, e.g., imposition of hands, invocation, etc.

- Participation in festivals, ceremonies, sacrifices, meals, etc.

- Congregational assemblies by processions, meetings, convocations, etc.

- Inspiration and symbolism by revelation, ecstasies, charms, etc.

However, in Africa, irrespective of the form it may take, it is usually accompanied by the proper use of designated ritual objects and the adequate employment of best fitting gesticulations, postures and actions, all harnessed in a pious religious atmosphere fostered by appropriate religious dispositions. This is why these actions done outside the required religious set up is believed not to produce the desired religious effect. Besides, rituals are often performed by designated people within the community and not an all comers affair. These special people includes the priest, prophets, diviners, traditional rulers, etc., and mostly the male folk.

Functionally, A. Wellace (1966) categorized ritual as technological, therapeutic or anti-therapeutic, salvific, social control and revitalization. Based on this categorization, Marx Weber regards rituals as of great importance in solving emotional problems of joy and sorrow, good and evil. It is ritual action which can enable people to feel their way to the proper handling of those issues, especially at the point of despair. Bacock corroborates Weber's position but notes that it may be permanent, long term or temporary. On this note, Ta Parson \& 
Ship (1957) refers to rituals as pattern maintenance and tension management.

For Ekarika (1984), ritual is more social and religious since "every ritual has a social-functional character that re-creates the people's solidarity and way of life and although there is a ritual for virtually every secular activity like eating, planting, harvesting, birth, death, etc., every ritual has a religious dimension and is taken seriously". The social dimension of ritual also expresses African ontology of communalism and social hierarchy which descends from the Supreme Being, the deities, the ancestors, elders and so on. This communism of reality is not limited to the world of man and the gods but involve even non-sentient beings, plants and animals. That is why they too are effectively employed in ritual actions.

Sociologically too, rituals has a communicative role between human and the Divine on the one hand and human and human in another. "This is its primary function; and though metaphorical and symbolic, this representation is not unfaithful. Quite on the contrary, it translate everything essential in the relations which are to be explained; for it is an eternal truth that outside of us there exist something greater than us, with which we enter into communion" (Bocock, 1974). "This is why we can rest assured that the practices of the cult, whatever they may be, are something more than movements without importance and gestures without efficacy" (Roszak, 1970).

Through rituals the older generation hand down the corpus of values and beliefs to younger generations. For instance, the beliefs in life after death, in the existence of ancestors, in re-incarnation, the existence of God, causality, etc., are all embedded in African funeral rituals. In addition, values and the consequences of their violation are expressed and portrayed in the ritual of purification, occasioned by sin, whether social or personal.

Ritual as a symbolic action expresses and communicates some hidden and mysterious realities that would otherwise have remained hidden and inexpressible. This explains why it is mostly used in religious circle as a way of bridging the gap between the sacred and the profane. Embedded in rituals too are the answers to esoteric and metaphysical questions like the existence of God, the problem of evil, nature of the soul, life after death, the nature of man, nature of reality and so on. It confers status and has transforming role that is metaphysical in nature.

Within traditional African society, ritual provides rules for action in the realm of the profane as well as supplying a bridge for passing unto the realm of the supernatural and sacred. In this way, ritual consists of symbolic action that expresses and communicates some hidden and mysterious messages. It is an avenue for making present in time and space actions that are futuristic in nature; tacitly providing avenue for conquering space and empowering man in its desire to control nature for his own advantage. Yinger (Ekarika \& Edet, 1979) captures this dimension of ritual thus:

For the Ibibio, ritual behaviour is a way of communicating with the divine and ritual forms the bedrock of social integration. It is seen as a salvation event in which an amalgam of the traditional faiths is shaped by and focused on the 
community's historical experience.

Through rituals the Africans are able to express values which are inexpressible, to experience these values that are mystical and to participate in them. Rituals then serve a veritable avenue of finding meaning to life through the bridging of the existential gap that exist between mortal and the Divine therefore, help to solve life's paradoxes and crises. Through rituals, the physical and the metaphysical realized and addressed in a symbolic-anthropomorphic terms thus naturalizing and humanizing the sacred thereby obliterate the divide between the two realm.

\section{Understanding African Ritual: African Ontology}

African ritual action is based first and foremost on the belief in existential reality besides the physical world. The hierarchical structure of African characterization of being gives credence to the existence of existents and reality outside the perceptible, physical world but which interact with the physical world in a kind of communal spiritualism to use C.S. Momoh's (2000) phrase. Actually, the universe is a unified whole with dual complements, the physical and the spiritual. Actions performed then in the physical world invariably have spiritual inspirations and causations. The employment and efficacy of rituals among the Africans is premised on African world view of harmonious monism, complementarity and integrated cosmology. Rituals action therefore pre-supposes an integrative connection between the ritual symbolic action physically performed and the desired effect or consequences.

This cosmological conception apparently influences both African pattern of thought (logic) and African perception of reality (epistemology). This Anyanwu (1987) and E. Edeh (1985) prefers to call "duality" to distinguish it from Western dualism and to refer to the notion of dialectics where two things functionally different are seen as essential and incomplete members of the whole to form a harmonious monism. This logic according to Anyanwu (1987), accepts the co-existence of opposing realities, each complementing the other. It denies absolutism, monolithism and completely diffuses the problem of dualism as evident in the Cartesian philosophy. This Anyanwu's submission is premised on the belief that "the world including $(\mathrm{x})$ has a missing link, which is something other than the thing $(\mathrm{x})$. The thing $(\mathrm{x})$ then persistently yearns for and struggles to capture this missing link. This is achieved at the time of complementation at which point $(\mathrm{x})$ realizes itself (Ijiomah, 1995). By implication, the physical is complemented by the spiritual and both can work harmoniously to achieve any desired effect. Both the physical and spiritual realities can influence and cause each other to action.

To properly understand the relationship among the various kinds of beings, then the notion of force as the fundamental causal and uniting factor is very important. It is the permeation of force or spirit in all things that is responsible for whatever exist. Force is here understood as life, energy, power, dynamism, 
strength or what P. Tempels (1969) technically referred to as vital force. Whatever exist, from the lowest to the highest being has a force. Every existence then exists in virtue of force, hence, different kinds of existence is a fraction (or function) of the degree of the life force in different beings. There is a supreme Spirit or Force, who is God, the force in the deities and the spirit of the ancestors, then the embodied spirit in man. There is also the spirits in animals, animate beings as well as inanimate beings. To get to the Supreme Being, man must go through the intermediary of ancestors and minor deities. This dynamism of spirits explains why the Africans invoke and talk to trees, rivers, mountains, stones, wood etc. In this way, the Africans believe the spirit which is the fundamental substance in reality can be harnessed and manipulated to their personal benefits.

\subsection{African Ritual and Time}

Time is a very important in understanding African ritual. All ritual actions are performed in specified time. But African notion of time is quite different from the Western notion of time, which regards time as "a dimension in which events take place and in which things have duration” (Meggart \& Mctaggart, 1968). Time in this case, is interwoven with succession of events and things, hence inextricable from succession of events and things hence inextricable from space. This must have informed the authors of the Great Soviet Encyclopaedia to describe time as a basic form, together with space, of the existence of matter. It exists objectively and is inseparably associated with moving matter. Time then forms a kind of a priori category as opined by Kant, for the existence of matter.

Among Africans, time is not something objectively existing in itself, it is neither associated with the clock nor with specific moment in life continuum. Time is measured in relation to man and the events that constitute man; the past, present, and the future are interwoven and ever present. Like the Igbo and the Yoruba, the Ibibio believe that "time is a part of nature, an event that is lived daily, naturally and rhythmically. In fact, the totality of man's existence with all its various aspects: religious, socio-cultural, politics, economic, personal and communal, is lived out in the context of time and rhythm that constitute the givens of his daily life (Iroegbu, 1995). "One lived with the gradual unfolding of the day (to work) and the night (to rest). This is also replaced in the progressive coming of the seasons; the rainy, to plant and fish; the day, to harvest, dry and stock. Man waits for and enacts feasts and market days in which various celebrations of life, in which love, worship, lives and deaths were celebrated" (Iroegbu, 1994).

This Iroegbu's idea of wounding time to event is refuted by Mbiti (1969). Mbiti argues that since the present is what is and can be expressed, then there is no idea of the future, as the future has no event, therefore, not yet there and has no time. In Mbiti's submission, "there are only two dimensions of time, a long past, a present and virtually no future" (cited in Iroegbu, 1995).

Ayoade (1984), on the other hand, sees Mbiti's exclusion of the future time as 
not applicable to all Africans. The Yoruba, for instance, regard the future as real just as the present. In essence, Yoruba metaphysics of time is a practical daily interaction of time past, time present and time future. It has to do with the past has come and gone but can be recalled and spoken of, therefore real. The present is the is, the now, the most real. In it we live and move and operate; the future though not yet there really, will nevertheless be there. Event will take place (Iroegbu, 1995). This explains why the Yoruba plans for events like farming, harvesting, festivities and other activities in the future. In summary, the reality of time (past, present and future) is the reality of concrete life lived in the circumstances of different projects: personal, public, individual and communal. These different aspects are also the aspects for which the basic existential platform call time (and space) is measured.

The Igbo, like the Yoruba, believe that "the past (Oge), the present (Ugbua) and the future (Obianihu) are not disjointed, they are relationally different phases of the one reality of temporality in which the human being realizes his being in the community, in the context of his environment" (Omoregbe, 1985).

Generally, time in Africa is measured by two realities-human or event and environment. The human reality comprises moments of birth, naming, puberty and adulthood. This Iroegbu (1995) calls egocentric time. A woman, for instance, may not be able to tell the exact age of the child but may link it with an important event that took place that year. In another dimension, time can be measured environmentally, in respect of, the economy involving ecology, rituals, socio-political and techno-developmental life. Iroegbu broadly groups this as celestial or cosmic and terrestrial or ecological time (Metaphysics, 308).

Celestial or cosmic time is measured by the rhythm of nature: day and night, sunrise and sunset. The Yoruba have AfeMojumo (early morning, that is, before sunrise, Iyaleta (late morning), Osan (afternoon), Irole or ojoro (early evening); the night is of two periods: low night and high night. The Ibibio, on their part, have mbang mbang usen ubok (early morning), usenubok (morning/dawn), uwemeeyo (afternoon), mbubiteyo (evening), and okoneyo (night). The measurement and duration of each period is measured by the position of the sun.

The physical features are used to measure time in the terrestrial/ecological scheme. The smallest unit of time, for instance, is measured by the twinkling of the eye. Short duration of time is measured by the drying up of the human sputum. Cockcrow indicates the beginning of the day while the night begins when the chickens beginning to return to roost. The human shadows are used to reckon how distant the time is to and from midday. At midday the shadow is shortest. These measures are, however, imprecise as the sunset varies from season to season and the cock can mistakenly crow before morning, or return to roost because of bad weather.

Ontologically, Ayoade (1984) describes African conception of time as being convertible and uninterrupted. It is an ever flowing locus in which all events take place. It is for human being to act in and according to time as it unfolds itself in days and nights. 
Rituals are therefore performed in time with the belief that "whatever is done today will have much influence with what happens next week" (Pratt, 1978). Like in Hopi (Pratt, 56), the African life is much occupied with ritual as preparatory and anticipatory exercise since they are led to deal with the future by working within the present situation. Through rituals, impressions are carried forward into the future and so believed to effect event which is of particular interest. In this way the African ritual performed within time involves and takes care of the future as an arena of anticipation and expectation.

\subsection{African Ritual and Space}

Like time, space plays a significant role in African ritual. Space is defined as "the attribute in which sizes, shapes, positions, distances and directions are varieties or modes and directions. Space is also seen as the non-temproal extension of things studied formerly in geometry (Williams, 1972).

Plato, Newton and Descartes held space as a unique frame or vessel in which particular objects and events are lodged. Aristotle, Leibniz and Ernest March regard space as consisting of relationship of distance and direction among objects and events. On another perspective, Newton, the Stoics and the Atomists upheld the possibility of an empty space, while Aristotle, Descartes and other followers of Einstein thought it absurd, contending that there can be no extension without something being extended.

The celebrated Newtonian and a Lockean conception of space as a unique frame or vessel, objectively real, in which particular objects and events are lodged, was rejected by Berkeley. Berkeley vehemently criticized the idea of independent existent space, which is absolute or relative depending on the nature of place. For Berkeley, the notion of absolute space, which is unperceivable to the senses, immovable and matched with itself is a supplantation of the notion of relative space (Gribanov, 1987). The question of absolute space beyond the sensible is not possible since in the common affairs of life, men never go beyond the earth to define the place of anybody (Robert, 1990).

Influenced by Berkeley's positions, Kant then sees space with time as subjective categories of the mind, which makes experience visible. Both Berkeley and Kant ended up denying space of any objectivity.

African thought on space is analogous to that of Berkeley and Kant. There is certainly no objective space as that would make it difficult to cover distances within a specified time frame. Space, for the African, is a creation of man at any interval for the achievement of any purpose.

In another dimension, Africans seem to be thinking of space as having two dimensions-the natural dimension and the mystical dimensions. The natural dimension of space has to do with the physical, visible space that separate one thing from the other or in which events take place. The mystical dimension of space is created by man through ritual action for the purpose of achieving some specified aim. For instance, sickness can be treated in proxy by ritually representing the person in a created space. Witches and wizards can cause their vic- 
tim to appear in a space of their creation for their hideous acts. This mystical space is then relative to the event performed.

In African traditional medicine both the objective and mystical space is used and it is only such understanding that can lead to a better appreciation of the dexterity and uniqueness of some African beliefs and practices like traditional medicine.

\section{Issues and Problems in African Conception of Ritual}

There have been trailing criticisms and rejection of ritual as primitive, superstitious and irrational. In fact, some regards it as the un-reflected baggage of cultural proclivity which in H.G. Gadamer's (1975) reckoning constitutes "prejudgements" or "idols" in Bacon's conception. Its association with symbolism compounds matters the more since symbolism does not have a one to one relationship with the thing they signify. It therefore generates the problem of identity between action and the symbolized objects or gestures. Since ritual actions are performed with anticipation of consequences and results, then the issue of necessary connection between cause and effect, among myriads of causes that could be linked to a particular event, becomes a concomitant problem as espoused by David Hume. Again, since ritual actions often employ physical objects as intervening medium, it necessarily implies a certain belief that can be interpreted as pantheistic, animistic or, a kind of Deus ex machina in materiality that Berkeley seriously repudiated. Its unpredictable nature makes it susceptible to manipulation and anchors mainly on the belief system of the people which can be questionable. The anthropomorphic nature of rituals makes the reality they potent questionable? Questions like whether these realities are real or mere human projections could arise. The epistemological import of some of the apparatus of rituals like divination, effigy, gestures, gesticulations, etc., makes the phenomenon of rituals to be susceptible to doubt. Their symbolism with myriads of possible interpretations cannot be exonerated from possible misinterpretation, misinformation and relativity in assessment and evaluation. With these telling criticisms, the status of African rituals as superstitious, irrational and illogical appears justifiable.

However serious these criticisms might be, one should not lose sight of the fact that African rituals are performed within certain backdrop of ontology, epistemology and belief system as shown above. Some of the criticisms are actually based on paradigms that are anti-thetical to African mind-set ab initio. Therefore, evaluating the rationality of African rituals using, for instance, Western typology would simply be jumping the gun of logic as paradigm for rationality cannot be a blindly fixed parameter. Let take that rationality as applicable to rituals mean that reasons can be offered for engaging in the ritual actions which are coherent in that they connect with one another to form a reasoned argument. There are indeed coherent and valid grounds upon which African ritual actions are performed based on a net work of beliefs informed by their ontology 
and epistemology, which are harmonious monism and integrative cosmology. And this may explain why Africans still recourse to it despite level of education and development. This must have informed Bocock's (1974) remarks that a belief cannot be termed irrational just because some sociologist and anthropologist have thought it to be false; it may continue to be believed because it is rationally related to other specific beliefs in a system.

Bocock's position no doubt is contestable, as one can argue that one can certainly show the rationality and non-rationality of a group's beliefs and ritual actions using basic notions of inference, contradictions, negation which "are claimed as universal to all notions of being rational in any language and culture but it should also be noted that this does not in any way falsify or confirmed these beliefs (Hollis, 1970). This must have been what Bocock (1974) had in mind when he argues that while rationality is a set of tool for deciding on the validity of the connections between reasons offered for conclusions, it cannot guarantee any particular ontology or any particular value system. The fact is that there are certain beliefs of men which are based on untested assumptions and pre-suppositions or are non-rational in nature that smoulderingly have tenacious and pervading influence on people even in the so called rational and civilized societies. This must have informed Vel De Waelhens' (1954) insightful and informative submission against radical rationalism that certain thoughts and actions are based on a "croyance", that is, a belief which cannot be directly called to question. This should not be construed as a flight into irrationalism; it only implies that "for any reflection at all, some data are taken initially for granted, without proof, and as it were by decree. They are believed or, as is rather more often the case, subconsciously presumed, at any rate, unquestioned" (Okere, 1983).

The criticism of irrationality of rituals then seems to stem from the overtone of radical rationalism which led to the Renaissance's conception of the irrational "as the forsaking of dispassion in favour of emotionalism, deliberation in favour of impulsiveness, articulation and logic in favour of rhapsodic declamation of some manner of non-verbal expression" (Roszak, 1970). And as observed by Bocock (1974) this is because emphasis is put solely on an aspect of man, the ego, on logic and the rational mind while leaving feelings, desires, pleasures and emotions out of consideration; yet it is these which often make experience meaningful for people. Ritual action, he submits should rather, be seen as a non-rational action, that is, that which cannot be assessed by rational criteria because they are inapplicable just like the feeling involve in loving a person. Though, for Jarvie and Agassi (1967) ritual action is best seen as to some extent rational and also irrational at times. And there is no particular paradigm of rationality or ontology which can be universality applied to evaluate such actions.

On another dimension, associating of causal potency of African ritual actions with superstitious belief seems a false supposition. The fact is that ritual actions among Africans are usually accompanied by spoken words for efficacy and potency. As I argued in Metaphysics of African Medicine (Etim, 2013), one of the 
possible explanations of the "word" dynamism is that, it is not spoken by anybody or haphazardly but by the medicine man, the diviner, the sorcerer, the witch and those who are believed to possess the latent power to unlock the secret of nature using set formulae. This action is anchored on the belief that all reality including inanimate object possess latent invisible vital force which the word ritual activates to cause the desired result, just like a pole of a magnet in close contact with iron fillings causes their re-alignment. So unlike the scientific wave hypotheses, the potency of the word is conveyed by the vital force and not by molecules, electrons and neutrons. Phenomena like hypnotism and related sciences in contemporary Western societies eloquently endorse and operate on the natural efficacy and power of the ritually spoken words. Spoken word in African context then is not as Locke will claim mere signs but also portentous similar to the practise of reciting the Lord's prayers and passages of the psalms as efficacious article of faith and means of combating enemies. Similarly, the various episodes of blessings and curses in Christian beliefs show the importance and efficacy of the use of words in all societies. This belief Bewaji argues "persist in the innermost recesses of Western psyche and comes readily to the surface at moments of existential travails of humanity, thus giving the lie to the veneer of technological hypocrisy that clouds the consciousness of the large segment of Western population" (2003). Surprisingly, while such practices and beliefs are accepted within the so called civilized societies, they are repudiated as unreasonableness among the Africans.

On another dimension, Fadahunsi (1988) argues against any scientific explanation of the causal potency of the spoken words, since words like wave in motion cannot be trapped to ascertain and identify the effect that corresponds to the particular wave. But such impossibility is no justifiable ground for denying the causal potency of the spoken word. To his mind, the wave hypothesis is metaphysical since the link between the uttering of words and the sound is unobservable. More so, it may be difficult to define the framework and assumptions within which the concepts involve in the hypothesis can be explained.

\section{Conclusion}

There is no doubt that the nature of African ritual makes it susceptible to criticisms of superstition, illogical and irrational that are levelled against it. However, it should be noted that these criticisms are based on an ontology which is alien to African conceptual scheme and that judging African rituals based on typologies and parameters arising from such proclivities would be jumping the bounds of logic, to properly understand, appreciate or evaluate African ritual require familiarization and taking into consideration African ontology of harmonious monism and integrative cosmology which inversely influence African belief in rituals. If this is actually applied then the accusation of primitivity, superstition and irrationality would not arise as African ritual would be evaluated in its own right and based on its ontology which guarantees and explains the reason for the persistent belief in its validity and relevance to the existential reality of the Afri- 
cans. In fact, as observed by Bocock (1974), African ritual and rituals in general can best be compared with some human phenomena like love that cannot be said to be either rational or irrational. At most, it can be said to be a non-rational action or a meta action for understanding African conception and perception of reality.

\section{Conflicts of Interest}

The author declares no conflicts of interest regarding the publication of this paper.

\section{References}

Anyanwu, K. C. (1987). The Idea of Art in African Thought. In D. Foistard (Ed.), Contemporary Philosophy: A Survey (Vol. 1, pp. 284-297). Dordevecth: Martins Nijhoff Press. https://doi.org/10.1007/978-94-009-3517-4_10

Ayoade, J. (1984). Time in Yoruba Thought. In Wright (Ed.), African Philosophy ( $3^{\text {rd }}$ ed., pp. 93-10.). Launham: U. P. A.

Bewaji, J. A. I. (2003). Beauty and Culture. Ibadan: Kenbine Press.

Bocock, R. (1974). Rituals in Industrial Society: A Sociological Ritualism in Modern England. London: George Allen and Unwin.

Edeh, E. (1985). Towards Igbo Philosophy. Chicago: University Press.

Ekarika, J. P. (1984). Maidenhood: Boudoir Mysteries in Traditional Puberty Initiation. Italy: Tipograpia.

Ekarika, J. P., \& Edet, R. N. (1979). From Nature to Divine: An Introduction to the Study of Religion. Italy: Tipograpia.

Etim, F. (2013). Metaphysics of African Medicine. Uyo: Minder Press.

Fadahunsi, A. (1988). The Logic of Incarnation. Journal of African Philosophy and Studies, $1,30-40$.

Fromm, E. (1950). Psychoanalysis and Religion. USA: Yale University Press.

Gadamer, H. G. (1975). Truth and Method. In J. Weisnsheimamer, \& D. G. Marshall (Eds.), London: Sheed and Ward.

Gluckman, M. (1962). Les Rites de Passage. In M. Gluckman (Ed.), Essays on the Ritual of Social Relations. London: Manchester University Press.

Gribanov, D. P. (1987). Albert. Einstein Philosophical Views and the Theory of Relativity. Mosco: Progress Pub.

Hollis, M. (1970). Reason and Ritual. In B. Wilson (Ed.), Rationality. Oxford: Basil Blackwell.

Ijiomah, C. O. (1995). Modern Logic. Owerri: A.P. Publications.

Iroegbu, P. (1994). Enwisdomization and African Philosophy. Owerri: International University Press.

Iroegbu, P. (1995). Metaphysics: The Kpim of Philosophy. Owerri: International University Press.

Jarvie, J. C., \& Agassi, J. (1967). The Problems of Rationality of Magic. British Journal of Sociology, 18, 55-74. https://doi.org/10.2307/588590

Mbiti, J. (1969). African Religions and Philosophy. London: Anchor Press.

Meggart, J., \& Metaggart, E. (1968). The Nature of Existence. London: Cambridge. 
Momoh, C. S. (2000). Nature, Issues and Substance of African Philosophy. In C. S. Momoh (Ed.), The Substance of African Philosophy (pp. 1-12). Auchi: African Philosophy Projects.

Okere, T. (1983). African Philosophy. New York: University Press of America.

Omeregbe, J. A. (1985). African Philosophy: Yesterday and Today. In B. O. Bodurin (Ed.), Philosophy in Africa: Trends and Perspective (pp. 1-10). Ife: University of Ife Press.

Oxford Advanced Dictionary (2010). Oxford: Oxford University Press.

Parson, T., \& Shib, E. (1957). Towards a General Theory of Action. Harvard: Harvard University Press.

Pratt, V. (1978). The Philosophy of Social Sciences. New York: Metheun. https://doi.org/10.4324/9780203392768

Ranger, T. O. (1972). The Historical Study of African Religion. London: Heineman Books.

Robert, M. (1990). The Great Books of the Western World: Vol. 35, Locke, Berkeley and Hume.

Roszak, T. (1970). The Meaning of a Counter Culture. London: Faber.

Tempels, P. (1969). Bantu Philosophy (King, C., Trans.). Paris: Presence Africaine.

Turner, V. W. (1962). The Ritual Process. London: Routledge and Kegan Paul.

Waelhens Van Der (1954). Science Awakening. Groningen: P Noordhoff.

Wellace, A. (1966). Religion: An Anthropology View. New York: Random House.

Williams, D. C. (1972). Space. In Encyclopedia Britannica (Vol. 25). Chicago: Benton Publishers. 